\title{
THE IMPORTANCE OF BANK CREDITS FOR AGRICULTURAL FINANCING IN SERBIA
}

\author{
Popović Svetlana ${ }^{1}$, Janković Irena ${ }^{2}$, Stojanović Žaklina ${ }^{3}$
}

\begin{abstract}
Summary
Agricultural loans present unutilized bank credit market segment in Serbia. This is not only missed profit opportunity for banks, but also serious deficiency that slows down the development of agriculture and rural areas. Paper uses FADN, NBS and bank balance sheet data in order to analyse supply and demand side of this credit market segment, with the aim to better understand the conditions for its development. Paper recommends better education of producers and lenders. Banks should better understand the requirements of agricultural producers and risks of the production to be able to create tailored credits. Insurance has very important role in specific risk hedging and can facilitate agricultural loans. There is also a need to adjust the conditions for obtaining subsidized loans, while the land size is considered as a key prerequisite for obtaining loans in the situation of large fragmentation of properties.
\end{abstract}

Key words: bank credits, subsidized loans, financing the agriculture, subsidies

JEL: $G 21, Q 14, H 71, R 51$

\section{Introduction- characteristics and the most important problems of agricultural production in Serbia}

Agricultural sector has an important role in Serbian economy. The share of agriculture, forestry and fishing in gross value added in 2016 was $6.5 \%$. It employed $18.5 \%$ of the total number of employed persons in 2017 and has a share of $7 \%$ in total export. Additionally if we add data for manufacture of food products, beverages, tobacco, than the share of such production in Serbian export is much more significant, around $22 \%$ (Statistical Office of the Republic of Serbia). Besides, agriculture plays an important role in the socio-economic and political context, since the government declares agriculture

1 Svetlana Popović, Ph.D., Assistant Professor, Faculty of Economics, University of Belgrade, Kamenička 6, 11000 Belgrade, Serbia, Phone: +381 113021 063, E-mail: ceca@ekof.bg.ac.rs

2 Janković Irena, Ph.D., Assistant Professor, Faculty of Economics, University of Belgrade, Kamenička 6, 11000 Belgrade, Serbia, Phone: +381 113021 046, E-mail: irenaj@ekof.bg.ac.rs

3 Stojanović Žaklina, Ph.D., Full Professor, Faculty of Economics, University of Belgrade, Kamenička 6, 11000 Belgrade, Serbia, Phone: +381 113021 162, E-mail: zaklina@ekof.bg.ac.rs 
as sector of strategic importance. Despite its importance, Serbian agricultural sector is faced with numerous problems, which significantly limit the utilization of its potentials.

The reform of the agricultural sector was one of the most problematic parts of the transition process. The economic and social problems of rural areas in Serbia stayed out of the main focus of policy makers. The systematic and comprehensive efforts for creating efficient mechanisms to activate and exploit their potentials are still missing. That is why this process caused social tensions and the growth of rural poverty and inequality. During the privatization of cooperatives and state agricultural enterprises, employment was not in the focus. At the same time, there was no systematic effort to encourage the growth of entrepreneurship and private initiative in rural areas, which significantly reduced opportunities for alternative employment and led to rising poverty among rural population. Rural areas make $90 \%$ of Serbian territory with almost 2/3 of total population (Manić, Popović, Stojanović, 2017). Nearly 52\% of rural households have no other income, except agricultural (Cvijanović, Subić, Paraušić, 2014). Inadequate economic structure of rural areas, high unemployment, low earning capacity, bad infrastructure and similar, caused a serious process of depopulation (depopulation process in Serbia is the most severe in Europe). Rural population, between two censuses decreased for almost $11 \%$, and the worst situation is in the South and East Serbia where decrease of 20\% was recorded (Manić, Popović, Molnar, 2012). Young people leave rural areas and there is a decreasing rate of population growth, which resulted in deterioration in the age structure. According to the census data, two thirds of the rural population is older than 65 , while the participation of young people up to 14 years is less than $14 \%$. In the future Serbia will be faced with a problem of lack of rural labour.

When it comes to agriculture, the main problems in rural areas could be summarized as follows: small farm size, outdated production technologies and machinery, and thus low productivity, the lack of adequate infrastructure (e.g. storage/cooling facilities, inadequate irrigation and drainage systems), insufficient, inadequate and inconsistent state support, limited economic activity, bad demographic and education structure of rural population, lack of entrepreneurship and initiatives, limited membership in cooperatives or associations of producers, and inadequate planning by local government. In many areas of production, producers are faced with uncertainty - price for their products isn't set in advance, they are variable, which make long term planning and investment difficult. Since the majority of producers are small and fragmented their bargaining power is very weak. Furthermore, one of the most important obstacles to the growth and development of agricultural sector is the lack of adequate financing.

\section{Financing of agriculture in Serbia}

Serbian agricultural sector has a range of different financial products available. They could be obtained from banks, state funds, leasing companies, microfinance organisations and integrators (large food processing companies that finance the agricultural production sector in the form of production inputs such as seeds, fertilizers 
and pesticides) (USAID, 2013). On the other side, the access to those funds is very limited for the majority of small producers, since they don't meet the loan conditions.

Main sources of financing of the agriculture in Serbia encompass the following: (1) Agrarian budget of the Republic of Serbia, Vojvodina and local municipalities; (2) Specialized state financial institutions' loans - Development Fund of the Republic of Serbia, Vojvodina's Development Fund for Agriculture, Vojvodina's Development Fund, and partly the Capital Investment Fund of Vojvodina followed by guaranties from Vojvodina's guaranty fund; (3) Subsidized loans of the Ministry of Agriculture; (4) Commercial bank loans; (5) Financial leasing; (6) IPARD program.

As in more developed countries financing in Serbia demands state support. ${ }^{4}$ Agricultural policy is still characterized by low allocation of resources to agrarian budged. Budget for the agriculture as a form of state support to agriculture is implemented dominantly through subsidization of agricultural production and investments. Budget for the agriculture presents $4.78 \%$ of the planned budget revenues of the Republic of Serbia in 2017 and is planned to be higher in 2018, reaching RSD 44 billion (Ministarstvo poljoprivrede, šumarstva i vodoprivrede. 2017). Financing of agriculture is, in addition to state budget, provided from development funds and municipalities' budgets.

Subsidized loans of the Ministry of agriculture are from 2004 provided from agricultural budget via commercial banks and were characterized by low interest rates. In 2017 the Ministry of agriculture subsidies the part of the interest on the loans provided by commercial banks. Loans with maturity of 1-3 years with grace period of one year, or 3-5 years to maturity are provided in local currency without FX clause. Fixed interest rate is $3 \%$ p.a. or in special occasions $1 \% .^{5}$ A physical person - the owner of a commercial family farm and an entrepreneur can exercise the right to credit support, provided that the total loan amount is up to RSD 6,000,000. A legal entity can exercise the right to credit support provided that the total loan amount is up to RSD 18,000,000 (Subvencije u poljoprivredi, 2017).

Commercial bank loans for agriculture were for years characterized by high interest rates, FX indexation, short term maturities often without grace period, with high pledge and insurance costs. Now, loans are provided with lower interest rates due to significant fall of the reference interest rate of the NBS in the previous period. Financial leasing is relevant financing vehicle from 2003 predominantly for procurement of agricultural machinery and equipment.

By becoming the candidate country in 2012 Serbia can apply for pre-accession funds. The relevant program for financing of the agriculture is the IPARD program with an aim to help the accessing counties to prepare for the implementation of the Common

4 e.g. CAP measures in EU and affordable agricultural loan financing in USA.

5 For physical person with a place of residence in an area with difficult working conditions in agriculture, that has reached a maximum of 40 years of age in the current year, or which is of a female sex.

EP 2018 (65) 1 (65-80) 
Agricultural Policy. The financing of agriculture from IPARD funds is realized on the principle of co-financing and pre-funding. The part of funds is provided from this fund and the rest should be financed from domestic public and private funds. According to the Ministry of Agriculture, the first tender for European funds is announced at the end of December 2017 for the purchase of tractors and other mechanization. Agricultural producers will have at their disposal 8.3 million euros, and they can count on the refund of 60 percent of the money invested. According to announcements from the Ministry, Serbia will be able to use a total of EUR 175 million from IPARD funds by 2020 (Ministarstvo poljoprivrede, šumarstva i vodoprivrede, 2015).

In order to test for the relevance of the subsidies in Serbian agricultural financing, we referred to FADN data. The analysis was made on the available FADN data on total subsidies (except for investments) for available years 2014 and 2015. Both years' samples were analysed (1,052 households in 2014 and 1,247 in 2015). Out of the total number of farms in both years, those who didn't receive subsidies in one year were excluded, and only the farms that exist in both samples were observed. The total number of analysed data was then reduced to 877 per year. From the total number of observed farms, there were 323 that faced the increase in subsidies in 2015 compared to 2014 , which represents $37 \%$ of all observed farms recipients of subsidies. The fall in subsidies occurred in 461 out of 877 farms, which represents 53\% of observed farms.

Table 1. The results of testing the significance of the difference in the average amount of subsidies in 2014 and 2015

\begin{tabular}{|l|r|r|}
\hline & Sample 2015 & Sample 2014 \\
\hline Average value of subsidies, in RSD & 357721.9789 & 470708.3 \\
\hline Variance & $3.7227 \mathrm{E}+11$ & $4.61 \mathrm{E}+11$ \\
\hline Number of observations & 877 & 877 \\
\hline Pearson's correlation coefficient & 0.764087615 & \\
\hline Number of degrees of freedom & 876 & \\
\hline $\mathrm{t}$ statistics & -7.477851428 & \\
\hline $\mathrm{P}(\mathrm{T}<=\mathrm{t})$ value one-sided test & 0.00 & \\
\hline $\mathrm{t}$ critical value, one-sided test & 1.646594942 & \\
\hline $\mathrm{P}(\mathrm{T}<=\mathrm{t})$ value double-sided test & 0.00 & \\
\hline $\mathrm{t}$ critical value, two-sided test & 1.962675695 & \\
\hline
\end{tabular}

Source: Calculation of the authors based on the FADN data

By testing the hypothesis on the equivalence of average value of subsidies in 2014 and 2015, it has been confirmed that there are statistically significant differences in the average level of subsidies in the observed two years for the observed farms. In addition, there was a decline in the average value of total subsidies in 2015 compared to 2014. This is a consequence of the change in subsidies per hectare, farms up to 20 hectares may be beneficiaries of these measures (earlier also larger farms had possibility to apply for 
subsidies per hectare). This also may indicate reforms of the state support - budget related payments will be governed toward institutional and structural reforms with the aim to create market environment for agricultural competitiveness growth in the future.

\section{Offer of bank loans for financing agricultural production}

From 30 banks that operated in Serbia in 2017, special offers for agricultural producers have 10 banks. Out of that number, Poštanska štedionica has only cash credits for agricultural producers and NLB bank offers only loans from the subsidy program of the Ministry of Agriculture. This means that only 8 banks have offers of agricultural credits. List of those banks is given in the table 2 :

Table 2. List of banks that have special offers of agricultural credits

\begin{tabular}{|c|l|c|}
\hline & The bank & $\begin{array}{l}\text { Rank in the first ten banks according to the } \\
\text { size of bank assets }\end{array}$ \\
\hline 1 & $\begin{array}{l}\text { AIK Banka (Agroindustrijsko komercijalna } \\
\text { banka) }\end{array}$ & 5 \\
\hline 2 & Banka Intesa & 1 \\
\hline 3 & Credit Agricole & \\
\hline 4 & Komercijalna Banka & \\
\hline 5 & Opportunity Banka & \\
\hline 6 & OTP Banka & \\
\hline 7 & ProCredit Banka & \\
\hline 8 & Sberbank & \\
\hline
\end{tabular}

Source: Web sites of banks; NBS (2017), Bankarski sektor u Srbiji, Izveštaj za IV tromesečje 2016. godine, Sektor za kontrolu poslovanja banaka, jun

Two largest banks in Serbia according to the size of bank assets (Intesa and Komercijalna banka) offer products specialized for agricultural needs, and AIK bank that is ranked as the $5^{\text {th }}$. Other banks are small, they don't belong to the group of the first ten. This means that banks didn't find their interest in creating loans for agricultural producers, so that this market niche is not very interesting to them. Only around 3.1\% of total bank loans granted are to registered agricultural producers (NBS). The level of market in the farm business should increase, they should rely more on their own capacities and market sources of funds, and not just on the state support, in any aspect of business. That is why it is important to find ways to overcome this situation, to analyse main obstacles for the development of agricultural loans market and discover ways to motivate profit oriented banks to exploit this market opportunities, in the situation where non-performing loans (NPL) to business are very high (15.6\%). Among the key industries, agriculture has the smallest level of non-performing loans- 4.7\% (NBS, 2017). 
Farms can obtain different short and long term loans from banks. These loans are designed for meeting short-term liquidity needs, purchasing working capital, as well as long-term investments in equipment and land. Usual minimal conditions for getting a bank loan are to have a registered farm with a minimum 1 year of farming experience and to have regular credit history (in the past 12 months, the client can't have reported active or historical delay in servicing its obligations to banks longer than 60 days). Sometimes other conditions exist as well, like the minimum surface of the land being cultivated, minimum annual income or production contract signed with a processor (Web sites of banks).

Agricultural producers can take loans with the purpose of financing working capital in agriculture (seeds, seedlings, fertilizers, protective chemicals, fuels, animal feed, livestock stock, and other raw materials in agriculture). These loans are with short term, up to 24 months, in dinars, dinars with a currency clause or in euros; minimal amount is 100,000 dinars (in some banks it goes up to 5,000 euros) and maximum $70 \%$ of the value of contracted production. Some banks offer grace period (when only interest is paid) of 12 months. Interest rate varies, it depends on the loan currency and exchange rate risk, whether it is fixed or variable, and different bank costs and fees. The overview of interest rates from banks' offer (only interest rates shown on web sites of banks) is given in the table 3 :

Table 3. Interest rates on bank short term credits for financing working capital for farms (an excerpt from the offer of banks)

\begin{tabular}{|c|c|c|c|c|}
\hline & \multicolumn{2}{|c|}{ Fixed interest rate } & \multicolumn{2}{|c|}{ Variable interest rate } \\
\hline \multirow{6}{*}{ Credits in dinars } & Nominal & Effective* & Nominal & Effective* \\
\hline & $6.5 \%$ & 6.75 & & \\
\hline & $9.5 \%$ & $14.23 \%$ & $5.75 \%+3 \mathrm{M}$ belibor & $15.88 \%$ \\
\hline & $9.45 \%$ & $16.05 \%$ & $\begin{array}{ll}6.17 \%+6 \mathrm{M} & \text { belibor } \\
(9.88 \%) & \\
\end{array}$ & \\
\hline & $24 \%$ & $27.05 \%$ & & \\
\hline & $24.75 \%$ & $33.06 \%$ & 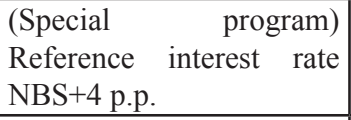 & $11.55 \%$ \\
\hline \multirow{4}{*}{$\begin{array}{l}\text { Credits in dinars with the } \\
\text { currency clause }\end{array}$} & $6.5 \%$ & 6.75 & & \\
\hline & $11.5 \%$ & $12.22 \%$ & & \\
\hline & $7.95 \%$ & $12.27 \%$ & & \\
\hline & $17.95-26 \%$ & & & \\
\hline Credits in Euros & $12-14 \%$ & & $6.95 \%+3 \mathrm{M}$ belibor & $12.72 \%$ \\
\hline
\end{tabular}

* Effective interest rate depends on the amount of a loan, while some costs are fixed, and thus the same independent of the amount of a loan. Beside, bank fees and other costs could differ.

Source: Bank's web sites 
For financing the permanent working capital, loans with longer maturity are also available, up to 5 years, (they are designed for animals breeding over 12 months, financing the production of perennial plants, restructuring of liabilities, permanent working capital to expand production and refinancing of loans in other banks). They could go up to 300,000 euros, in dinars or dinars with the currency clause, with grace period up to 6 months (in the case of perennial plants grace period could be up to 24 months). Interest rate goes from $14 \%$ nominal or $40.36 \%$ effective interest rate for credit in dinars and $9.95 \%$ nominal or $28.97 \%$ effective interest rate.

Agricultural producers could obtain also investment loans, designed for financing of construction/adaptation/reconstruction of economic facilities; infrastructure works on the holding; formation/extension of the basic herd, reproductive livestock fund; raising perennial plantations; irrigation and anti-hail protection systems; greenhouses, cold storages, dryers, storage capacities and related equipment; equipment for processing of primary agricultural products; purchases of used machinery and equipment; purchase of agricultural land and economic facilities; and refinancing of existing loans. Credit could be in dinars, dinars with currency clause or Euros, with the maturity up to 120 months (in some cases with the maturity of 15 years) depending on the purpose and currency clause, grace period is up to 24 months, available amount is from 5,000 (somewhere 10,000) -100,000 Euros or maximal amount depends on the credit capacity of the borrower. Interest rate depends on the currency of the loan, whether it is fixed or variable, as shown in the table 4 (only interest rates shown on web sites of banks):

Table 4. Interest rates on bank investment credits for agriculture (an excerpt from the offer of banks)

\begin{tabular}{|c|c|c|c|c|}
\hline & \multicolumn{2}{|c|}{ Fixed interest rate } & \multicolumn{2}{|c|}{ Variable interest rate } \\
\hline & Nominal & Effective & Nominal & Effective \\
\hline \multirow{3}{*}{ Credits in dinars } & \begin{tabular}{|l|}
$8.95 \%$ first 36 months, \\
after $5.5 \%+3 \mathrm{~m}$ Belibor
\end{tabular} & $10.58 \%$ & $5.25 \%+3 \mathrm{~m}$ Belibor & $10.27 \%$ \\
\hline & $13 \%$ & $13.83 \%$ & & \\
\hline & $18 \%$ & $19.61 \%$ & & \\
\hline \multirow{4}{*}{$\begin{array}{l}\text { Credits in dinars with } \\
\text { the currency clause }\end{array}$} & $6.5 \%$ & $6.7 \%$ & $6 \mathrm{M}$ Euribor $+6.5 \%$ & $6.48 \%$ \\
\hline & $12 \%$ & $12.7 \%$ & $6 \mathrm{M}$ Euribor $+12.5 \%$ & $13.02 \%$ \\
\hline & $14 \%$ up to 36 months & $24.95 \%$ & $\begin{array}{l}7.25 \% \text { first } 36 \mathrm{months} \text {, } \\
\text { after } 7.25 \%+6 \mathrm{~m} \text { Euribor }\end{array}$ & $10.8 \%$ \\
\hline & \begin{tabular}{|l|}
$6 \%+6 \mathrm{~m}$ Euribor \\
$(4.76 \%)$
\end{tabular} & & \begin{tabular}{|l}
$5.75 \%$ (variable, tided to \\
$3 \mathrm{~m}$ Euribor) \\
\end{tabular} & \\
\hline \multirow{2}{*}{ Credits in Euros } & $12-20 \%$ & & $6.45 \%+3 \mathrm{~m}$ Euribor & $7.27 \%$ \\
\hline & $19.95-28 \%$ & & & \\
\hline
\end{tabular}

Source: Banks'web sites

Agricultural producers can also obtain loans to satisfy their short term liquidity needs, in form of liquidity loan or overdraft. Overdraft is designed for securing the daily liquidity of the client. Money can be used at any moment, without prior notice, and 
can be used repeatedly if necessary and returned until the expiration date. One bank offers fixed nominal interest rate on overdraft of $31.76 \%$ (effective interest rate is $32.64 \%$ ). Liquidity loan could be received in the amount of 50,000-300,000 dinars with the repayment period of 12 months and nominal fixed interest rate of $16 \%$ (effective interest rate is from $21.35 \%$ ).

Some banks offer loans in cooperation with the Guarantee Fund of AP Vojvodina for financing of registered agricultural holdings, residing in the territory of AP Vojvodina. Loans are designed for various purposes, like the purchase of agricultural machinery and equipment, agricultural land, purchase of energy efficient equipment and equipment for using renewable energy sources. Available amount, depending on the purpose of credit is from 5,000 (in some banks 10,000 Euros)-250,000 Euros, maturity is up to 10 years, grace period is 12 months, in dinars or dinars with currency clause.

Banks have also some specific offers of agricultural loans like revolving credits, credits with the possibility of changing the repayment plan, credits with the insurance (like Generali), refinancing loans, loans in the cooperation with some development funds (like German development fund KfW) etc.

\section{Agricultural credits - Demand side analysis}

Analysis of agricultural credits market would be incomplete without the analysis of the demand side - what amount of credits has been granted to farms, with what purpose, how important those credits are for banks and who are the main creditors. It is also interesting to analyse who are the main users of bank loans.

Table 5. Banks- main agricultural lenders in Serbia, 2016

\begin{tabular}{|c|l|c|c|}
\hline & The bank & $\begin{array}{l}\text { Amount of granted loans to } \\
\text { agricultural producers, in 000 } \\
\text { dinars/ (share of bank credit } \\
\text { portfolio) }\end{array}$ & $\begin{array}{l}\text { Bank share in total amount } \\
\text { of agricultural loans granted, } \\
\text { 2016 }\end{array}$ \\
\hline 1 & ProCredit Banka & $24,647,397 /(34.31 \%)$ & $43.58 \%$ \\
\hline 2 & Banca Intesa & $13,935,439 /(5 \%)$ & $24.64 \%$ \\
\hline 3 & Komercijalna Banka & $6,549,353 /(13 \%)$ & $11.58 \%$ \\
\hline 4 & Sberbank & $5,519,392 /(3.6 \%)$ & $9.76 \%$ \\
\hline 5 & Credit Agricole & $4,133,884 /(4 \%)$ & $7.31 \%$ \\
\hline 6 & OTP Banka & $1,035,118 /(3.2 \%)$ & $1.83 \%$ \\
\hline 7 & AIK Banka & $691,085 /(0.6 \%)$ & $1.22 \%$ \\
\hline 8 & Opportunity Banka & $45,400 /(0.45 \%)$ & $0.08 \%$ \\
\hline
\end{tabular}

Source: Banks'financial reports, author's calculation

The most important agricultural lender in Serbia is ProCredit bank that granted almost $45 \%$ of total agricultural loans in 2016. Since those loans make slightly above a third 
of banks' loan portfolio, one could say that this bank is specialized for financing the agricultural sector. On the second place is Intesa with almost a quarter of the total sum of granted agricultural loans. However those loans make only $5 \%$ of banks' credit portfolio. Komercijalna banka is on the third place according to the share in total agricultural loans, that make $13 \%$ of credit portfolio of the bank. Sberbank had a share of almost $10 \%$ in bank agricultural loans in 2016, while the share of those loans in bank credit portfolio is 3.6\%. Credit Agricole granted 7.3\% of agricultural loans, which made $4 \%$ of bank credit portfolio. Remaining 3 banks have insignificant share on the market of agricultural loans.

Only three banks have the share of agricultural loans higher than $10 \%$, which proves that banks are unwilling to penetrate this market. Banks perceive agricultural loans as riskier than loans to other industrial sectors. It is not so easy to estimate creditworthiness of applicants from agricultural sector, especially if they are small farmers. Very often there is a problem of collateral and how to evaluate it. Also, the value of future production is uncertain, as well as future revenues due to unsure price of the final product and repurchase, great dependence on weather conditions, uncertainty of production, etc.

On the other side, in the past few years banks that are the largest agricultural creditors recorded significant growth of those loans. The sum of bank claims on registered agricultural producers grew strongly since the mid of 2008, as showed on the graph 1.

Graph 1. Bank claims on registered agricultural producers

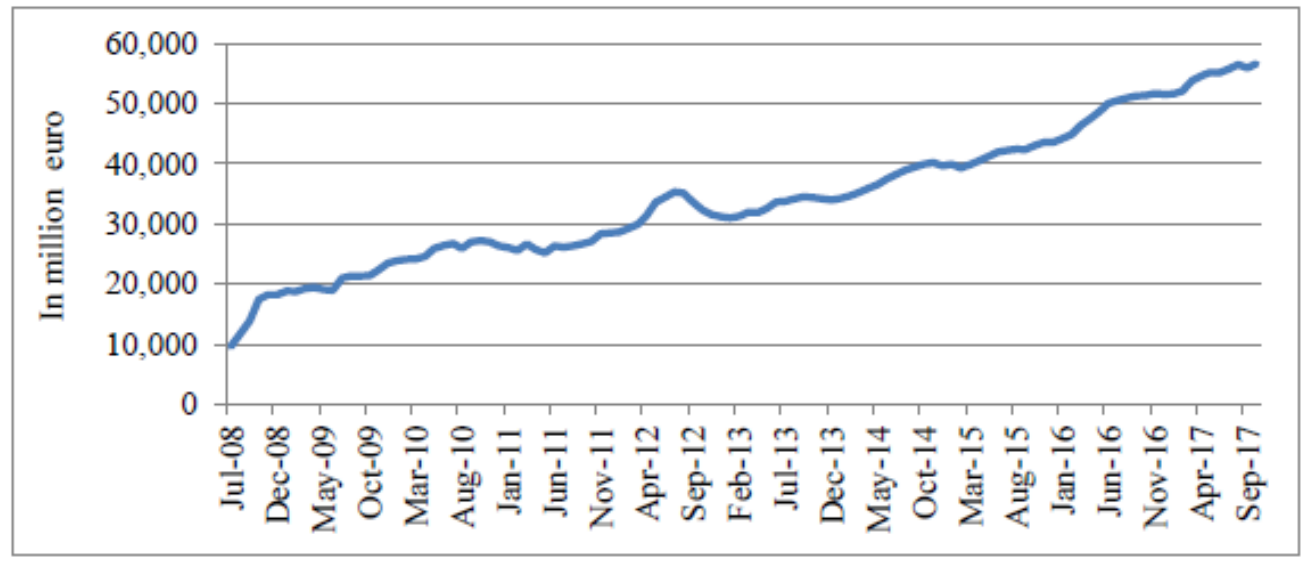

Source: NBS, Statistics

The amount of granted loans to agricultural producers increased 6 times in observed period. This is partly due to the fact that banks are trying to replace a smaller volume of operations in other credit markets and find new unexploited or insufficiently exploited market segments. Some banks in their strategic goals for the next period include more extensive crediting of agriculture. Still, there is a problem of adequate financing of small and medium farms, since in the focus of agricultural growth strategy are clients with bigger holdings and greater creditworthiness from Vojvodina (banks are already active in 
lending to farms in Vojvodina) and parts of Central Serbia. Some banks plan to introduce new products that are better suited to specific needs of agricultural producers, like credit lines for the purchase of land with a maturity of 10 years or more, as well as loans for the purchase of equipment with more flexible collateral (Komercijalna banka, 2016).

Analysis of the structure of bank claims on registered farms helps better understanding the purposes for which agricultural loans have been granted. It is given in the graph 2:

Graph 2. Bank credits to registered agricultural producers, by purpose

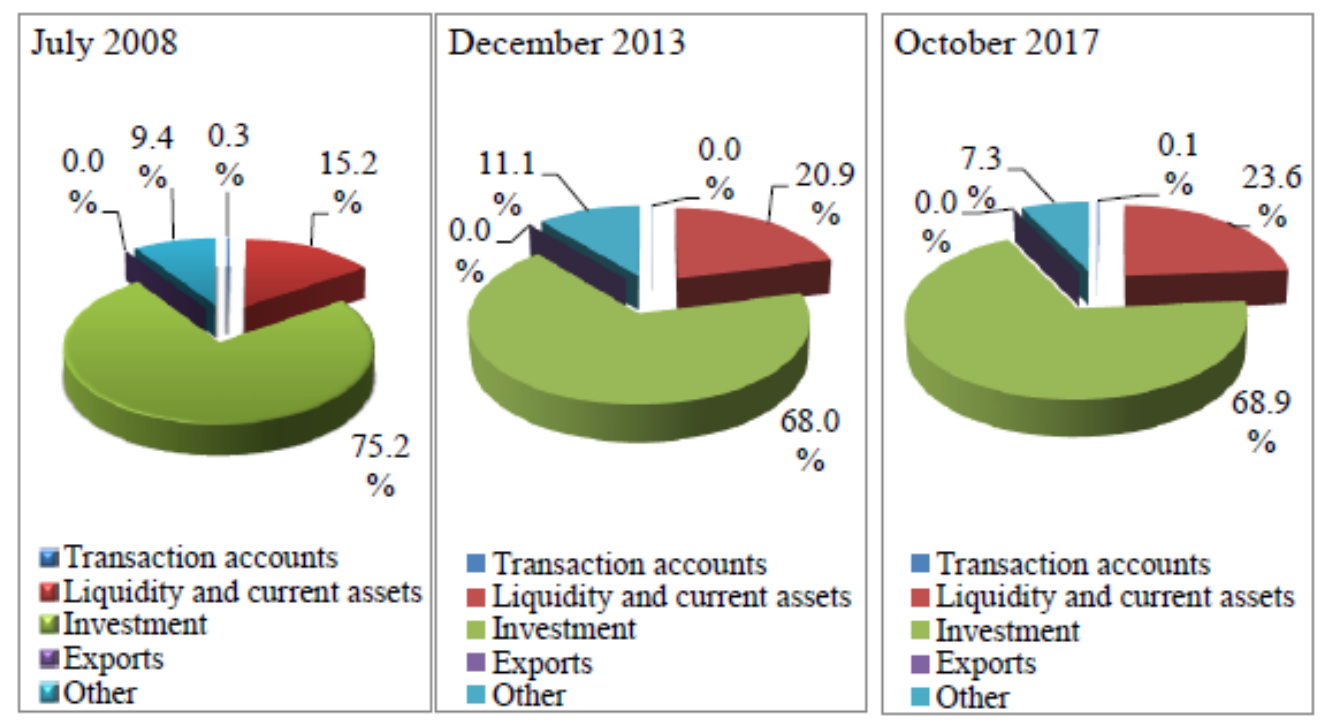

Source: NBS, Statistics

Registered agricultural producers used bank credits mostly for investment purposes. According to Vučković, Veselinović, Drobnjaković (2017) part of assets in inventories should be also financed with long-term loans. In 2008, 3/4 of total bank loans were with investment purpose. After that, their share decreased and now it is around 2/3. Farms increasingly used credits for covering liquidity needs. While the share of these loans in 2008 was around $15 \%$, at the end of 2017 it was almost $24 \%$. The share of cash loans is very small, in 2017 it was only $0.3 \%$. The share of overdraft loans is also insignificant. These are the most expensive loans, so we can't expect higher farm reliance on these loans in the future. Unfortunately, increasingly reliance on liquidity loans shows the shortage of revenues, so that current income is insufficient to cover the needs for financing the current assets. These are also very expensive loans. Share of export loans is almost zero. This is probably due to the fact that producers are not selling their products directly to foreign importers, but to (few) larger domestic exporters.

Farm accountancy data network gives indication about the main beneficiaries of agricultural loans, according to the size of agricultural holding, type of production and purpose. Although data were collected based on the sample (not all producers are 
included) the use of a stratified sample should accurately demonstrate the structure of these loans. Graph 3 shows the share of farms of different size in obtained bank credits.

Graph 3. Farm size and bank credits

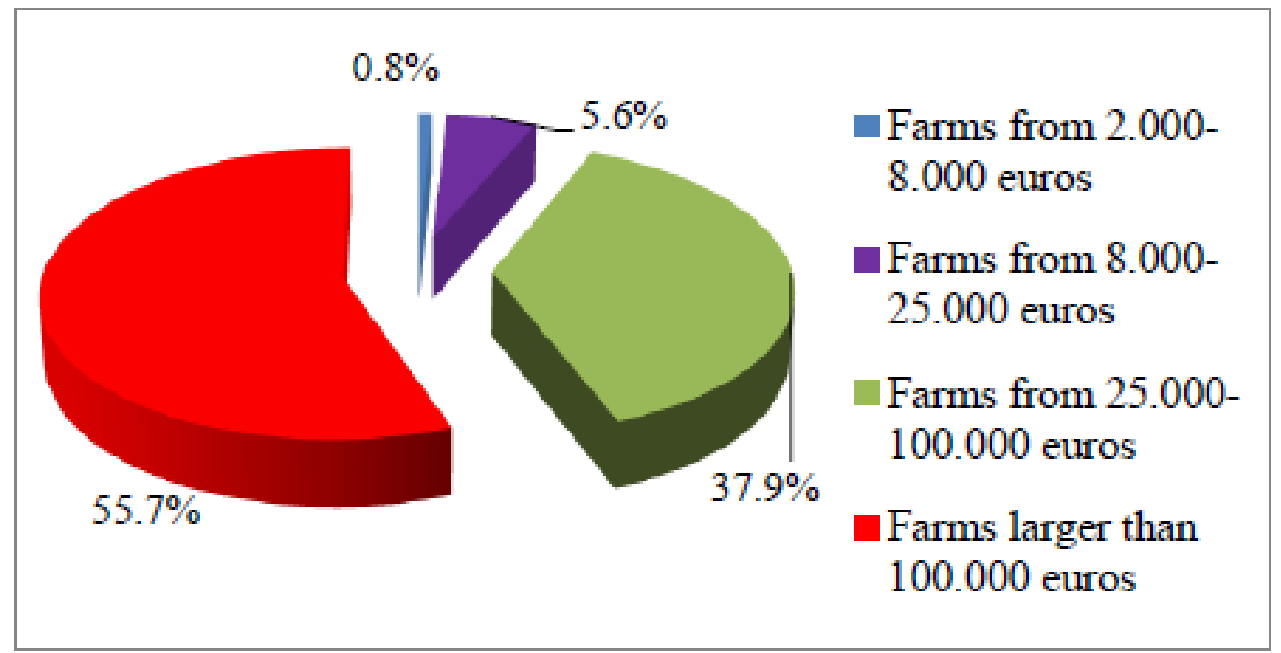

Source: Farm accountancy data network, 2015

FADN data prove previous statement that vast majority of bank credits are granted to larger farms. Farms with economic size larger than 25,000 Euros participate with almost $94 \%$ in obtained credits, out of that, the largest farms with almost $60 \%$. The participation of the smallest farms, with the economic size up to 8,000 Euros is negligible. These conclusions are similar to ones found in Sedlar et al. (2016, p.1225). There is obvious need for the improvement of financing of smaller farms, since average economic size of Serbian family farm is 4,990 Euros (family farms present 99.5\% of farms in Serbia), and almost $86 \%$ of the total number of farms has economic value up to 8,000 Euros (Cvijanović, Subić, Paraušić, 2014). Graph 4. shows the term structure of loans obtained by interviewed farmers, depending of farm size. 
Graph 4. Term structure of used agricultural loans, according to farm size

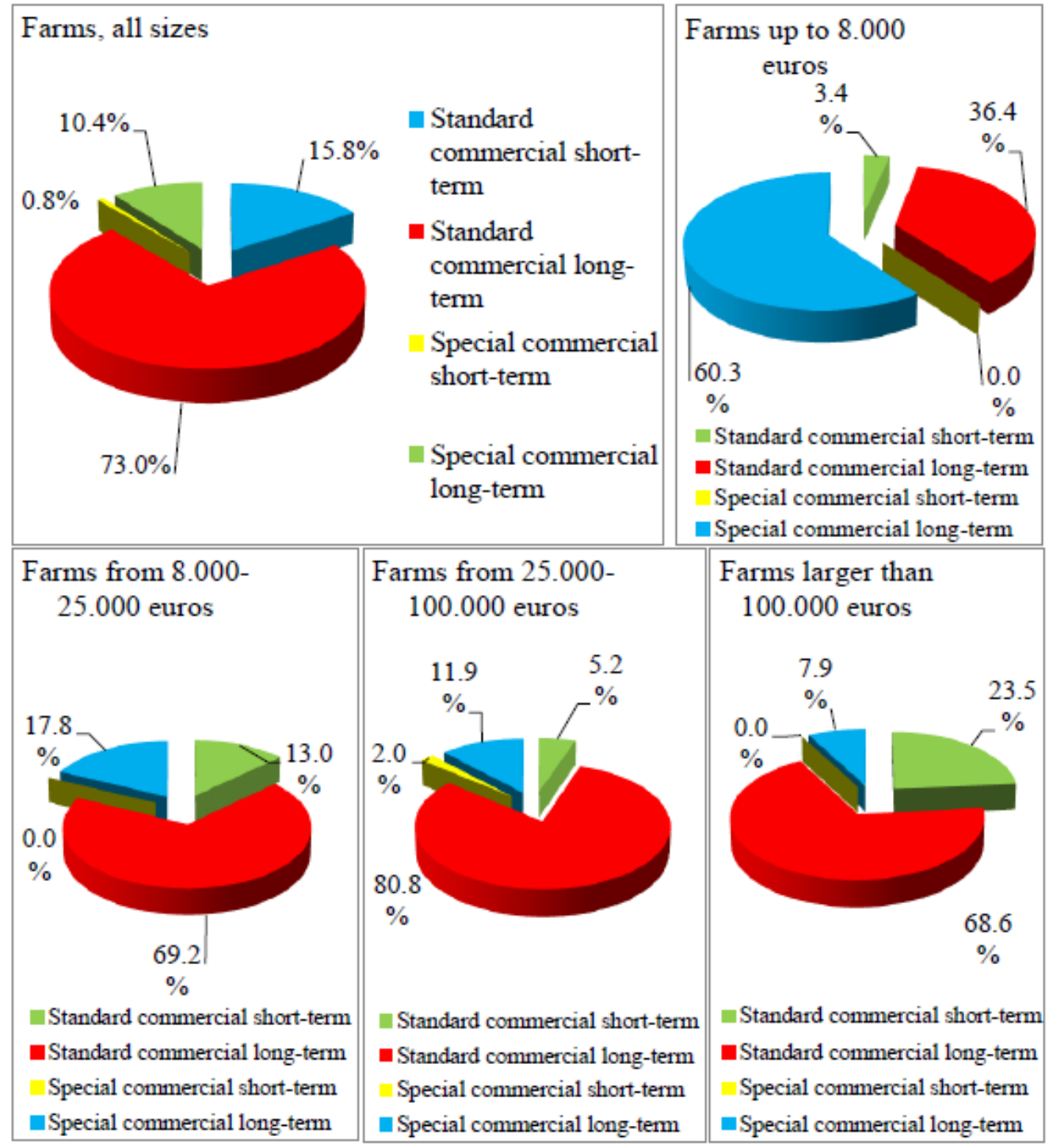

Source: Farm accountancy data network, 2015

The standard long-term commercial loans count for almost $3 / 4$ of their credit obligations. Long term commercial credits are used by the most interviewed farms which economic size is from $25.000-100.000$ Euros, slightly above $80 \%$. Opposite, small farms with economic size up to 8.000 Euros relied much less on standard commercial loans. Special commercial loans are predominantly used by small farms- more than $60 \%$, these loans are also important source for farms from 8.000-25.000 Euros, but larger farms tend to use it less. Special commercial short term loans are the least popular in satisfying financial needs of farms of all sizes, their share in obtained bank loans is 
zero or close to zero. Small farms don't use too much standard commercial short-term loans, but for larger enterprises they are very important, almost a quarter of obtained bank loans. It is also interesting to mention the structure of used credits according to the type of the production. According to FADN data, farms that produce vegetables, crops and flowers used the largest part of bank credits, while the smallest share was used by producers of livestock and in diary sector.

\section{Conclusion}

Agriculture in Serbia is characterized by low profitability due to specific seasonal and extensive production cycle, low specialization of production, low capacity utilization, low turnover ratio, higher exposure to natural hazards in latest years, and inadequate financing vehicles. Although there are different financial sources, their characteristics and conditions are not well tailored-made to satisfy needs of agricultural producers.

Agricultural production is still dependant on the state support- through subsidies from the agrarian budget, but this is insufficient. Besides, the agricultural development policy hasn't been consistent. Agricultural sector support and regulations have been changed a lot of times (even in the same year) and payments to producers have been delayed, which backed unstable and unfavourable economic environment for agriculture. There is a need for farms to rely more on their own capacities and market sources of fundswhere bank credits have significant role.

Agro-crediting in Serbia is not even close to its full potential. Small number of banks deals with this type of lending (effectively only 5 banks) mostly due to the lack of recognition of the potential of this market segment, as well as the lack of the necessary technology and methodology for processing credit claims and assessing the risks of the business of agricultural producers. Business analysis is more demanding and implies knowledge of all agricultural processes and technologies grown by certain crops and livestock production.

Specific risks on this market segment are mostly related to an open air production, a very high impact of climate factors and weather conditions. Insurance would significantly reduce risks, but this type of insurance is still unpopular with agricultural producers, largely due to the number of claims denied or inadequately paid by insurance companies. Majority of agricultural production is uninsured. Adequate insurance can significantly reduce the risks and increase banks' interest in lending to this sector. This can be used as a potential motivator for agricultural producers in the future, by lowering interest rates when processing the credit claim for insured production.

Banks are dominantly oriented towards larger producers and agricultural companies (larger than 25,000 Euros), smaller producers are "removed" from the market. This is economic and social problem, since slightly above $97 \%$ of total number of farms has economic value up to 25,000 Euros. Term structure of granted bank loans is favourable, while $3 / 4$ is the share of investment loans. On the other side, there is a negative tendency of increasing the use of liquidity loans- for financing the current assets. These are 
among the most expensive loans, together with overdraft and cash credits, and their usage increases the production costs. Overall, bank loans are characterized by high interest rates, FX indexation (only very short-term loans are in dinars without currency clause), high pledge, insufficiently long terms.

Subsidized loans are the most attractive both for the banks and the producers, but they are granted on the basis of the land that the farm is cultivating, and there is a problem of property fragmentation. The vast majority of smaller producers do not satisfy the conditions for those loans. Additionally, agricultural policy measures should be more governed toward institutional and structural reforms with the aim to create market environment for agricultural competitiveness growth in the future. The role of the commercial banks might be crucial in co-financing of agricultural investments based on the IPARD scheme.

It is necessary to work on the education of agricultural producers as well as creditors in order to improve the functioning of agricultural loans market. Agricultural producers must be properly informed about all the benefits of insuring the production, lending, and advancement of technological processes in order to further develop the production. On the other hand, lenders need to understand the needs of agricultural producers, to analyse previous production results and anticipate future production to be able to adequately respond to credit needs and ensure timely and adequate crediting without the risk of over-indebtedness of agricultural producers- and earn profit on this unutilized market segment.

Finally, the future of financing of the Serbian agriculture should rely more on financial instruments such as commercial papers, warehouse receipts trading and longer term debt instruments. In addition, commodity derivatives could be used as instruments for hedging the relevant price risks.

\section{Literature}

1. Agroklub (2017). Budžet 2018: Kako će se trošiti novac? Available at: https://www. agroklub.rs/poljoprivredne-vesti/budzet-2018-kako-ce-se-trositi-novac/37803/ (24.12.2017).

2. Cvijanović D., Subić J., Paraušić V. (2014). Poljoprivredna gazdinstva prema ekonomskoj veličini i tipu proizvodnje u Republici Srbiji, Popis poljoprivredePoljoprivreda u Republici Srbiji 2012 (ISBN 978-86-6161-129-2), Republički zavod za statistiku, Republika Srbija, Beograd.

3. Komercijalna banka (2016). Annual Report, Belgrade. Available at: http://www. kombank.com/pdf/godisnji 2016.pdf (18.12.2017).

4. Manić E., Popović S., Molnar D. (2012). Regional Disparities and Regional Development: The Case of Serbia. Mittelungen der Osterreichishen Geographischen Gesellschaft, Band 154, pp.191 - 210. Wien.

5. Manić, E., Popović, S., Stojanović, Ž. (2017). Rural Space Development in Post- 
Transition Countries: The Case of Serbia. New Developments in the Rural Space of Central and South-East Europe, Proceedings of the meeting of the Working Group on Central Europe in conjunction with the German Congress of Geography, Berlin, September 30, 2015, Institut fuer Stadt-und Regionalforschung, Verlag der Oesterreichischen Akademie der Wissenschaften, Wien, pp.11-29.

6. Ministarstvo poljoprivrede, šumarstva i vodoprivrede (2015). 175 miliona evra iz IPARD programa. Available at: http://www.minpolj.gov.rs/175-miliona-evra-izipard-programa/ (24.12.2017).

7. Ministarstvo poljoprivrede, šumarstva i vodoprivrede (2015). Farm accountancy data network. Database.

8. Ministarstvo poljoprivrede, šumarstva i vodoprivrede (2017). Budžet za 2017. godinu veći za 3,2 milijarde dinara. Available at: http://www.minpolj.gov.rs/budzetza-2017-godinu-veci-za-32-milijarde-dinara/ (23.12.2017).

9. NBS (2017). Bankarski sektor u Srbiji, Izveštaj za IV tromesečje 2016. godine, Sektor za kontrolu poslovanja banaka, jun Available at: http://www.nbs.rs/internet/ latinica/55/55 4/kvartalni izvestaj_IV_16.pdf (16.12.2017).

10. NBS Statistics, Available at: $\underline{w w w . n b s . r s}$.

11. Sedlar, O., Jovin, S., Pejanović, R., Ćirić, Z., Eremić-Đođić, J. (2016). Access to Finance to Micro, Small and Medium Business Units in Serbian Agribusiness. Economics of Agriculture (63) 4, pp. 1219-1235, Belgrade, Available at: http:// www.bsaae.bg.ac.rs/images/Ekonomika\%20kompletna/2016/EP\%204\%202016. pdf (20.12.2017).

12. Statistical Office of the Republic of Serbia, Available at: http://www.stat.gov.rs/ WebSite/public/ReportView.aspx (12.12.2017).

13. Subvencije u poljoprivredi (2017). Subvencionisani krediti Ministarstva poljoprivrede u saradnjisa komercijalnim bankama. Available at: http://subvencije. rs/krediti/subvencionisani-krediti-ministarstva-poljoprivrede/subvencionisanikrediti-ministarstva-poljoprivredesumarstva-vodoprivrede/ (22.12.2017).

14. USAID Enabling Project (2013). Agricultural Finance in Serbia- Status and Recommendations, Available at: http://www.bep.rs/baza_znanja/documents/ commodity-exchange/Agricultura $1 \% 20$ Finance $\% 20 \mathrm{in} \% 20 \mathrm{Serbia} . \mathrm{pdf}$ (11.12.2017).

15. Vučković, B. Veselinović, B. Drobnjaković, M. (2017). Financing of Permanent Wordking Capital in Agriculture. Economics of Agriculture 3/2017, pp. 1065 1080, Belgrade. Available at: http://www.bsaae.bg.ac.rs/images/Ekonomika\%20 kompletna/2017/EP\%203\%202017\%201q.pdf (18.12.2017).

16. Web sites of banks. 


\title{
ZNAČAJ BANKARSKIH KREDITA ZA FINANSIRANJE POLJOPRIVREDE U SRBIJI
}

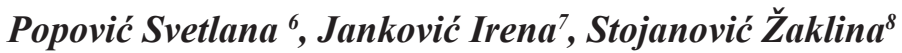

\begin{abstract}
Sažetak
Poljoprivredni krediti predstavljaju neiskorišćeni segment kreditnog tržišta u Srbiji. Za banke to je promašena prilika za realizaciju profita, a za državu ozbiljan nedostatak koji usporava razvoj poljoprivrede i ruralnih područja. Rad analizira ponudu i tražnju na ovom segmentu kreditnog tržišta, kako bi utvrdio uslove za njegov razvoj, na bazi FADN, NBS i podataka iz bilansa stanja banaka. Autori ističu potrebu za boljom edukacijom proizvođača i zajmodavaca. Banke bi trebalo da bolje razumeju potrebe poljoprivrednih proizvođača $i$ rizike ove proizvodnje, kako bi kreirale potrebama prilagođene kredite. Proizvođači treba da budu obavešteni o prednostima osiguranja njihove proizvodnje, jer osiguranje ima veoma važnu ulogu u zaštiti od rizika specifičnih za poljoprivrednu proizvodnju. Takođe postoji potreba za prilagođavanjem uslova za dobijanje subvencionisanih kredita, jer je veličina zemljišta ključni uslov za dobijanje ovih kredita, a postoji velika fragmentacija zemljišta.
\end{abstract}

Key words: bankarski krediti, subvencionisani zajmovi, finansiranje poljoprivrede, subvencije

6 Svetlana Popović, Ph.D., Docent, Ekonomski fakultet, Univerzitet u Beogradu Belgrade, Kamenička 6, 11000 Beograd, Srbija, tel.: +381 113021 063, E-mail: ceca@ekof.bg.ac.rs

7 Janković Irena, Ph.D., Docent, Ekonomski fakultet, Univerzitet u Beogradu Belgrade, Kamenička 6, 11000 Beograd, Srbija, tel.: +381 113021 046, E-mail: irenaj@ekof.bg.ac.rs

8 Stojanović Žaklina, Ph.D., Redovni profesor, Ekonomski fakultet, Univerzitet u Beogradu Belgrade, Kamenička 6, 11000 Beograd, Srbija, tel.: +381 113021 162, E-mail: zaklina@ekof.bg.ac.rs 